\title{
The Brazing Behavior of Aluminum-Steel Cladding Strip with Pre-Cladded Brazing Layer Used in Air Cooling System of Power Plants
}

\author{
Chang SUN ${ }^{1, \mathrm{a}}$, Xiao-jun ZHANG ${ }^{2}$, Long LI ${ }^{3}$, De-jing ZHOU ${ }^{4}$ \\ 1,2,3,4 Yin Bang Clad Material Co., Ltd., Wuxi Jiangsu, China
}

\begin{abstract}
The brazing behavior of 3003 fin assemble with 4343(filler layer)/4A60(transition layer)/08Al(steel layer) brazing sheet (the ratio of filler layer thickness to transition thickness were constant 1:2) were investigated. This study elucidates the brazing results vary with the layer thickness and brazing temperatures. Results showed that keeping the holding time at brazing temperature constant (the holding time of this study was 10 minutes in all brazing progress), under the condition of brazing temperature less than or equal to $580^{\circ} \mathrm{C}$, thinner filler layer led to well formed joint, while thicker filler layer led to defects at brazing joints because of poor mobility. When brazing temperature was up to $600{ }^{\circ} \mathrm{C}$, a thinner transition layer trended to lead to the formation a thick intermetallic compounds layer on the Aluminum-Steel surface. It was inferred that Si diffused from molten filler metal to the interface of transition layer and steel layer and promoted the formation of intermetallic compounds. Furthermore, it was found that in the surface away from brazing joints, with lower $\mathrm{Si}$ content, the intermetallic compounds were mainly $\eta\left(\mathrm{Fe}_{2} \mathrm{Al}_{5}\right)$, while higher Si content region nearby brazing joints trended to form $\tau_{5}\left(\mathrm{Al}_{8} \mathrm{Fe}_{2} \mathrm{Si}\right)$ and $\tau_{6}\left(\mathrm{Al}_{4.5} \mathrm{FeSi}\right)$. Meanwhile, a transition layer with thickness above $134 \mu \mathrm{m}$ could avoid the formation of intermetallic compound. The optimum brazing process was that temperature range was $590^{\circ} \mathrm{C}$ to $595^{\circ} \mathrm{C}$ with 10 -minutes holding time and the transition layer thickness was suggested to be equal or more than $134 \mu \mathrm{m}$.
\end{abstract}

\section{Introduction}

With the development of electric power technology, the high parameter steam turbine unit of the thermal power plants are increasing year by year. So there is a greater demand for water resources in the cooling system of the power plant. Air-cooling system for power

* Corresponding author:dejing.zhou@cn-yinbang.com 
plants was developed in 1970s in order to alleviate the contradiction between the shortage of water resource and the increasing water demand in power stations. Not only can the air-cooling system improve the efficiency of heat exchanger, but it also can save at least $75 \%$ of the water compared with the traditional ways [1].

One of the key technologies of producing air-cooling system for power plant is the manufacturing technology of the tube-fin heat exchanger. The air-cooling tube-fin exchanger is mainly manufactured by brazing the base tube and the fin. Base tube, made of aluminum-steel clad prepared by rolling-bonding process, has both good mechanical properties of the steel and good thermal conductivity of aluminum alloy[2-3]. The fin, made of aluminum alloy which has good thermal conductivity, is brazed on the base tube. Heating up to melt the brazing filler, with the aid of capillary force, the filler filled into the gap between fins and base tube so that brazed joint formed by metallurgical bonding after solidification[4]. Aluminum-steel cladding strip with pre-cladded brazing layer has been developed in recent years. The filler layer is hot rolled with transition aluminum layer. The as-rolled sheet and steel are cold rolled by the rolling mill. Then, the monolayer layer fin and the three layer aluminum-steel clad are brazed. This can reduce the times of rolling and save cost. Besides, the filler coating on the surface of aluminum-steel clad is benefit to avoid erosion of the fin.

The brazing temperature and the thickness of transition layer are the key parameters of brazing process. During this process, it is prone to cause erosion defects of the transition layer. After the transition layer was penetrated by the molten filler, the Si element accumulated at the interface of aluminum-steel, which leads to the formation of brittle compounds at the interface of aluminum-steel. The brittle compounds can severely damage the bonding of the aluminum and steel, weaken the mechanical properties of material[5]. Thus it greatly reduced the service life of the material. In this paper, the monolayer 3003 fin and three layers of aluminum-steel clad material were brazed at different temperature and different thickness of the 4A60 transition layer by controlled atmosphere brazing $(\mathrm{CAB})$ process. Silicon's effect on the erosion defects of the transition and formation of the intermetallic compound(IMC) at the interface was investigated.

\section{Experimental Procedure}

Three layers of aluminum-steel cladding strip 4343/4A60/08Al (filler layer/ transition layer/steel) with different thickness and 3003 fin were chosen as the experimental materials. Elements and specifications of the materials are shown in table 1 and table 2. 
Table 1 elements (wt.\%) and properties of the fin and three layers of aluminum-steel cladding strip

\begin{tabular}{|c|c|c|c|c|c|c|c|c|c|}
\hline Elements & $\mathrm{Si}$ & $\mathrm{Fe}$ & $\mathrm{Cu}$ & $\mathrm{Mn}$ & $\mathrm{Zn}$ & $\mathrm{Ti}$ & $\mathrm{Al}$ & solidus & liquidus \\
\hline 3003(fin) & 0.55 & 0.5 & 0.125 & 1.15 & - & 0.02 & bal & $643^{\circ} \mathrm{C}$ & $654^{\circ} \mathrm{C}$ \\
\hline 4343(filler layer) & 7.5 & 0.19 & 0.01 & 0.03 & 0.005 & 0.01 & bal & $577^{\circ} \mathrm{C}$ & $613^{\circ} \mathrm{C}$ \\
\hline 4A60(transition layer) & 0.81 & 0.28 & - & - & 0.01 & 0.02 & bal & $642^{\circ} \mathrm{C}$ & $655^{\circ} \mathrm{C}$ \\
\hline 08Al(steel) & - & bal & - & 0.25 & - & - & - & $>1000^{\circ} \mathrm{C}$ & $\begin{array}{l}>1000 \\
{ }^{\circ} \mathrm{C}\end{array}$ \\
\hline
\end{tabular}

Table 2 thickness of the layers of aluminum-steel cladding strip and aluminum layer

(filler layer:transition layer $\approx 1: 2$ )

\begin{tabular}{|c|c|c|}
\hline Thickness $(\mathrm{mm})$ & Filler layer $(\mu \mathrm{m})$ & Transition layer $(\mu \mathrm{m})$ \\
\hline 2.03 & 62 & 112 \\
\hline 2.47 & 76 & 134 \\
\hline 2.70 & 87 & 155 \\
\hline
\end{tabular}

Firstly, the specimens were scrubed with alcohol to remove grease and other impurities on the surface. And then the specimens were soaked in the $\mathrm{NaOH}$ solution with mass fraction of $10 \%$ for $2 \mathrm{~min}$, so that the oxide film on the the specimens was removed. On the filler surface of the aluminum-steel cladding strip, fluoaluminate flux suspension (NOCOLOK, $\mathrm{AlF}_{3}-\mathrm{KF}$ ) with mass fraction of $10 \%$ was painted after rinsed. Then the specimens was dried at $80^{\circ} \mathrm{C}$ in the oven. The fin was placed on the filler surface of the aluminum-steel cladding strip and ensure good contact between the two. Then the assembles were put into the brazing furnace to carry out brazing under the condition of Ar gas protection.

During the brazing process, to make the specimens heated uniformity, take the stage of heating and thermal insulation. The furnace was first evacuated to a vasumm less than $100 \mathrm{~Pa}$, purged with high-purify (99.999\%) Ar, and then heated to $500^{\circ} \mathrm{C}$ at the rate of $20^{\circ} \mathrm{C}$ $/ \mathrm{min}$ in the flowing Ar. The furnace was heated to $550{ }^{\circ} \mathrm{C}$ at the rate of $5{ }^{\circ} \mathrm{C} / \mathrm{min}$ after holding at $500{ }^{\circ} \mathrm{C}$ for $10 \mathrm{~min}$. And then, the furnace was heated to brazing temperature in $10 \mathrm{~min}$ after holding at $550{ }^{\circ} \mathrm{C}$ for $10 \mathrm{~min}$. After holden at brazing temperature for $10 \mathrm{~min}$, the furnace was cooled to room temperature at a rate of $30^{\circ} \mathrm{C} / \mathrm{min}$. Brazing temperature was $570{ }^{\circ} \mathrm{C} 、 575^{\circ} \mathrm{C} 、 580{ }^{\circ} \mathrm{C} 、 585^{\circ} \mathrm{C} 、 590{ }^{\circ} \mathrm{C} 、 595^{\circ} \mathrm{C} 、 600{ }^{\circ} \mathrm{C}$, respectively. In this experiment, all holding time at final brazing temperature were 10 minutes. 


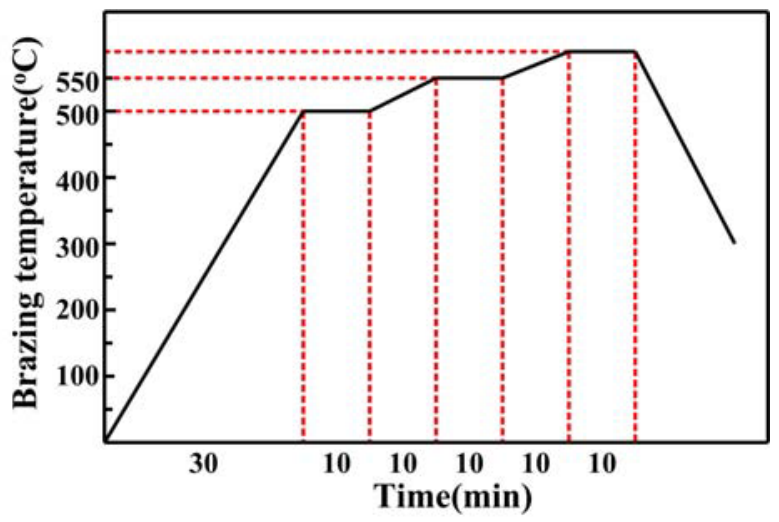

Fig.1 Temperature rising curve of brazing process

The interface morphology between the transition and steel layer was observed by Zeiss optical microscope. JSM scanning electron microscope (SEM) and EDAX energy dispersive spectrometer were utilized to study the microstructure and various phases of the interface.

\section{Results and Discussion}

\subsection{Effect of Temperature on Brazing Behavior}

Figure 2 and table 3 shows the different experimental results after brazing at different temperature. Brazing temperature can affect the liquidity of the filler effectively. It was able to form brazed joint when the thickness of the filler layer was $62 \mu \mathrm{m}$, under the condition of $570{ }^{\circ} \mathrm{C} \sim 580{ }^{\circ} \mathrm{C}$. However, in figure $3 \mathrm{a}-\mathrm{b}$, there were parts of the position can't form metallurgical combination. But when the filler layer thickness $\geqslant 76 \mu \mathrm{m}$, the filler cannot be fully melted. Owing to poor liquidity of the molten filler, the capillary force cannot completely overcome viscous resistance force. Therefore in figure $3 \mathrm{f}-\mathrm{g}$, only a small part of the filler flowed to the brazed seam, formed brazed joint with defects. Figure $3 \mathrm{c}-\mathrm{d}$ and $\mathrm{h}-\mathrm{j}$ show that when the brazing temperature range was $590{ }^{\circ} \mathrm{C} \sim 595^{\circ} \mathrm{C}$, the filler melted with good liquidity. The capillary force can overcome viscous resistance force. The filler flowed to the brazed joint, formed perfect brazed joint. When the thickness of the filler layer was $112 \mu \mathrm{m}$, it was unable to form brazed joint. In figure $3 \mathrm{e}$, a lot of intermetallic compound was generated at the aluminum-steel interface. Figure $3 \mathrm{i}$ shows that when the transition thickness $\geqslant 134 \mu \mathrm{m}$. The brazed joint coud be formed and intermetallic compound was not found. 


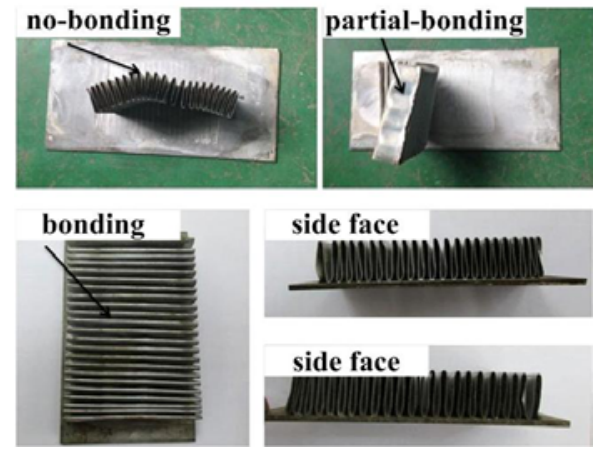

Fig.2 Schematic diagram of brazing results

Table 3 Brazing Results Of Aluminum-Steel Cladding Strip With Different Thickness Of Filler Layer And

Transition Layer

\begin{tabular}{|c|c|c|c|c|}
\hline Temperature $\left({ }^{\circ} \mathrm{C}\right)$ & Holding time $(\mathrm{min})$ & $62: 112(\mu \mathrm{m})$ & $76: 134(\mu \mathrm{m})$ & $87: 155(\mu \mathrm{m})$ \\
\hline 570 & 10 & 0 & 0 & 0 \\
\hline 580 & 10 & $\bullet$ & 0 & 0 \\
\hline 590 & 10 & $\bullet$ & $\bullet$ & $\bullet$ \\
\hline 595 & 10 & $\bullet$ & $\bullet$ & $\bullet$ \\
\hline 600 & 10 & 0 & $\bullet$ & $\bullet$ \\
\hline
\end{tabular}

When brazing temperature range was $570^{\circ} \mathrm{C} \sim 580^{\circ} \mathrm{C}$, the filler cannot be fully melted. Poor liquidity of the filler led to poor brazed joint. When brazing temperature $\mathrm{T} \geqslant 600{ }^{\circ} \mathrm{C}$ and the transition layer thickeness $\leqslant 112 \mu \mathrm{m}$, the brazed joint cannot be formed. The brazing penetration increased with brazing temperature rising. The optimum brazing temperature range was $590^{\circ} \mathrm{C} \sim 595^{\circ} \mathrm{C}$.
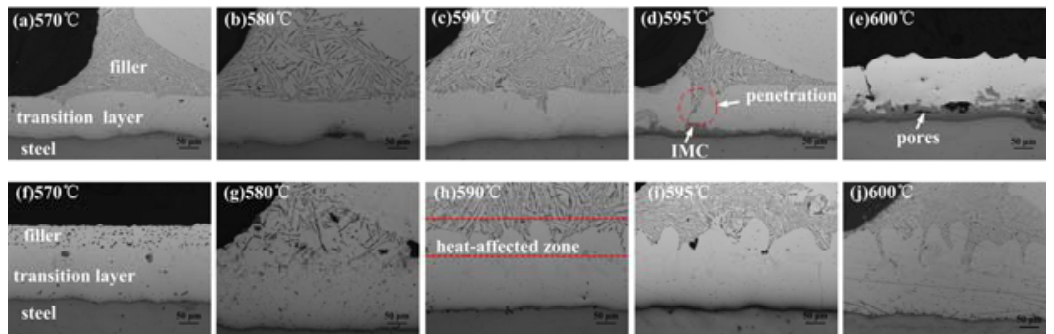

Fig.3 The Results Of Brazing With Different Thickness Of Filler Layer And Transition Layer (A-E) 62:112 $\mu \mathrm{m}$ And (F-J) 76:134 $\mu \mathrm{m}$ Under Different Brazing Temperature Conditions 


\subsection{Erosion Behavior of the Transition Layer}

Table 4 Intermetallic Compound (Imc) With Different Thickness Of Filler Layer And Transition Layer

\begin{tabular}{|c|c|c|c|}
\hline Temperature $\left({ }^{\circ} \mathrm{C}\right)$ & $62: 112(\mu \mathrm{m})$ & $76: 134(\mu \mathrm{m})$ & $87: 155(\mu \mathrm{m})$ \\
\hline 570 & $\square$ & $\square$ & $\square$ \\
\hline 580 & $\square$ & $\square$ & $\square$ \\
\hline 590 & $\square$ & $\square$ & $\square$ \\
\hline 595 & $\square$ & $\square$ & $\square$ \\
\hline 600 & $\square$ & $\square$ & \\
\hline$\square$ without IMC, $\square$ IMC &
\end{tabular}
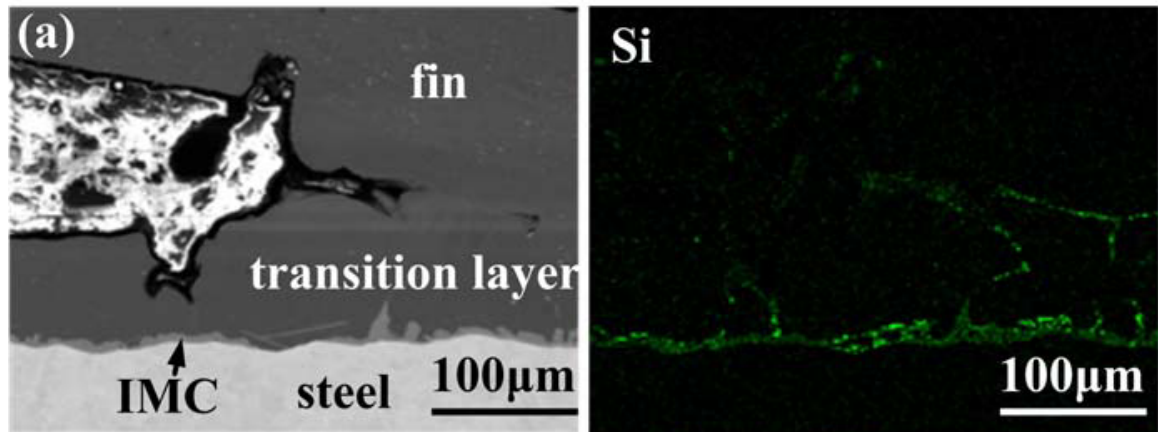

(b)

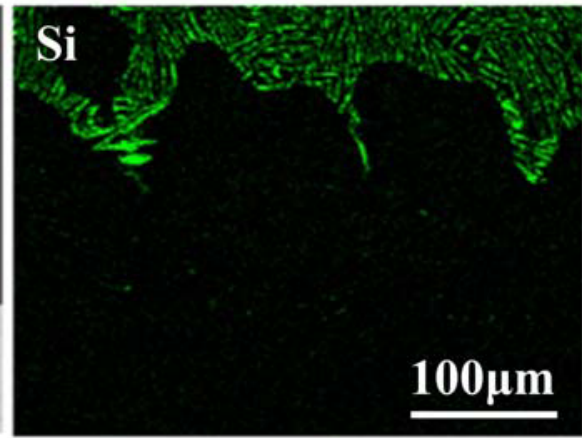

Fig.4 SEM images and Si element distribution at the brazed joint with filler layer: transiton layer were (a)

$62: 112 \mu \mathrm{m}$ (b) $76: 134 \mu \mathrm{m}$

The Si content in the filler (7.5wt.\%) was much higher than that in the transition layer (0.81wt.\%). Si diffused from filler (high concentration) to transition layer (low concentration). The diffusion behavior of Si had an important influence on the erosion of the transition layer. During brazing process, the molten filler gathered in brazed joint with the aid of capillary force. The silicon's diffusion led to silicon's segregation at grain boundaries of the transition layer. The increasing of Si content led to the decreasing of the melting point of grain boundaries. When the melting point of the grain boundaries was lower than the brazing temperature, the grain boundaries melting occured, which can produce grain boundary penetration. The phenomenon that liquid metal penetrated into the 
solid metal grain boundaries, namely the grain boundary penetration[6]. The cause of penetration was that a large number of crystal defects existed in grain boundaries. The crystal lattice distortion seriously increased the energy of atoms in this region, leading to the increasing of the frequency of the atoms. Therefore, the grain boundary was conducive to the diffusion of elements[7], which was the high speed channel for the diffusion of Si.

When the transition layer thickness was $112 \mu \mathrm{m}$, filler penetrated transition layer along the grain boundaries of the transiton layer at $600^{\circ} \mathrm{C}$. Filler infiltrated to the aluminum-steel interface, transverse diffused along the aluminum-steel interface. At the same time, the increasing of filler at the aluminum-steel interface reduced melting point of the aluminum that was adjacent to steel, which led to the formation of intermetallic compounds. According to the Kirkendall effect, in figure 3e some pores appeared in the transition layer[8] due to the the diffusion rate of $\mathrm{Al}$ atoms was faster than $\mathrm{Fe}$ atoms. The silicon's diffusion from brazing filler to transition layer during brazing heating process led to form Si deficiency in filler layer, resulting in decreasing fluidity of brazing filler and more chance to form defects, such as no-bonding and pores. At the brazed joint, filler almost completely lossed in figure 4a. Excessive diffusion of the filler caused pit and even perforation, which weakened the mechanical properties of the brazed joint.

When the transition layer thickness was $134 \mu \mathrm{m}$, the transition layer was corroded by the molten filler but not be penetrated. The molten filler diffused to the surface of the transition layer, until reached saturation. Then, the surface of the transition layer began to dissolve into the molten filler. Under the condition that the molten filler was not flowing, the molten filler first solidificated along the surface of the transition layer. Due to the transition layer corroded to a certain depht by the molten filler, the heat- affected zone formed after the filler solidification. Figure $3 \mathrm{~h}-\mathrm{j}$ showed that coarse $\alpha$-Al distributed in the filler. However, interfacial compound was not found at the interface of the aluminum-steel. In figure 5 , we can see that the higher the brazing temperature, the larger the heat-affected zone[9]. The increasing of Si content in transition layer can promote the formation of intermetallic compound. Therefore, in order to prevent $\mathrm{Si}$ diffusing into the interface of aluminum-steel effectively, the transition layer thickness was at least $134 \mu \mathrm{m}$. 


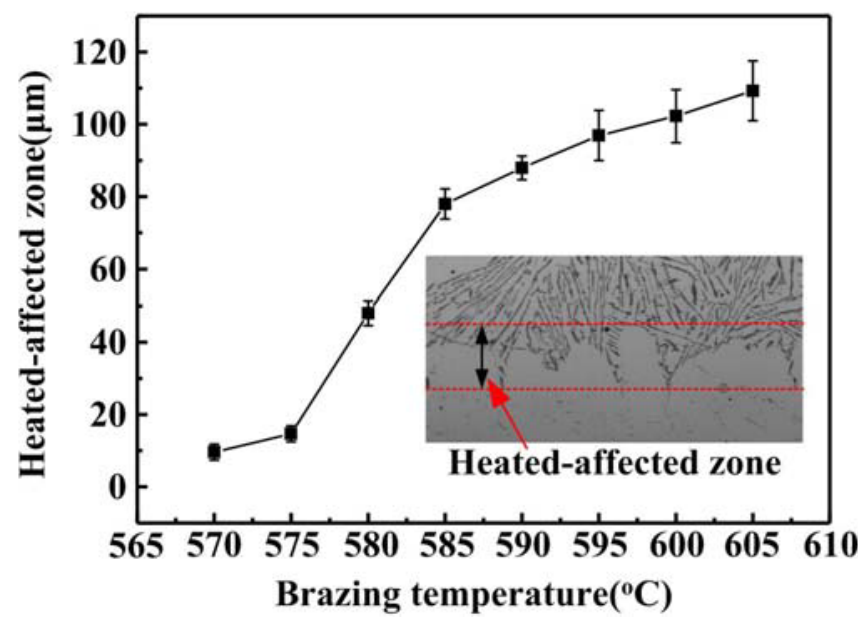

Fig.5 The Curve For Range Of Heat Affected Zone-Brazing Temperature

\subsection{Intermetallic compound of aluminum-steel interface}

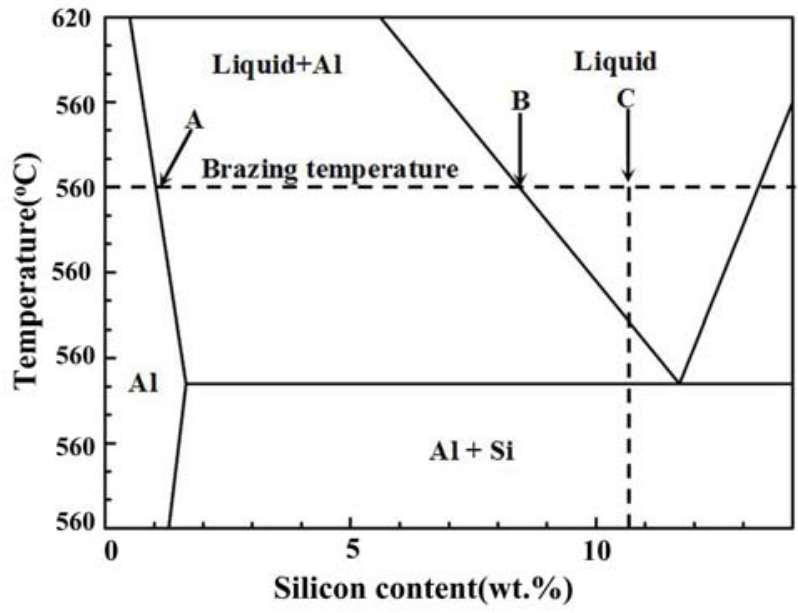

Fig.6 Al-Si phase diagram[10]

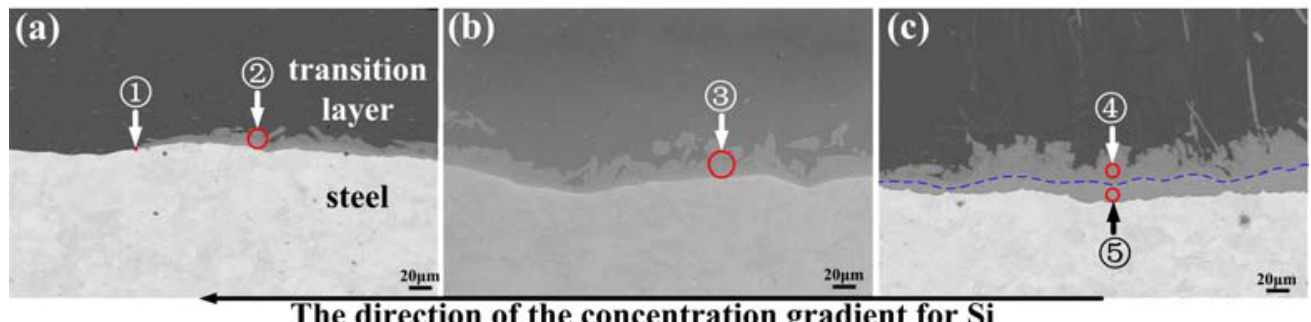

Fig.7 SEM images of the intermetallic compounds at aluminum-steel interface 
Table 5 Energy Spectrum Analysis(Atom Percentage) Of Aluminum-Steel Brazing Interface

\begin{tabular}{|c|c|c|c|c|}
\hline Label & $\mathrm{B}$ & $\mathrm{C}$ & $\mathrm{D}$ & $\mathrm{E}$ \\
\hline $\mathrm{Al}$ & 71.85 & 70.81 & 67.84 & 71.55 \\
\hline $\mathrm{Si}$ & 0.91 & 2.63 & 15.31 & 9.85 \\
\hline $\mathrm{Fe}$ & 27.24 & 26.56 & 16.85 & 18.6 \\
\hline Phase & $\mathrm{Fe}_{2} \mathrm{Al}_{5}$ & $\mathrm{Fe}_{2} \mathrm{Al}_{5}$ & $\mathrm{Al}_{4.5} \mathrm{FeSi}$ & $\mathrm{Al}_{8} \mathrm{Fe}_{2} \mathrm{Si}$ \\
\hline
\end{tabular}

The Si in filler diffused to the interface of aluminum-steel along the grain boundary of transition layer in the form of penetration. Then $\mathrm{Si}$ diffused along the interface of aluminum-steel in transverse direction. The increasing of Si at the interface will increase the diffusion rate of aluminum atom and promote the formation of intermetallic compound(Figure 7a、b).

The termination point of IMC is in (1) position. IMC were embeded in the transition layer, which is a block like morphology(Figure 7b). The Si content of the (1)(2)(3) point of IMC was not much increased. At the point of (1)(2)(3), Al-Fe interdiffusion phenomenon mainly occurs. The reaction process was the following three stages[11].

In the first stage, Al-Fe interdiffused at the interface, forming a certain range of diffusion layer. The diffusion coefficient of $\mathrm{Fe}$ atoms in aluminum is larger than the diffusion coefficient of $\mathrm{Al}$ atoms in iron. There will be a large number of $\mathrm{Fe}$ atoms across the interface with the increasing of temperature or time. On side of the aluminum layer, Fe reacted with aluminum generating $\mathrm{FeAl}_{3}(\theta$ phase) accroding to $\mathrm{Fe}-\mathrm{Al}$ phase diagram[12]. $\mathrm{Al}$ atoms continued to diffuse into the iron through $\mathrm{FeAl}_{3}$, forming $\mathrm{Fe}-\mathrm{Al}$ solid solution on the iron side. Fe atoms diffused into the transition layer through $\mathrm{FeAl}_{3}$, forming $\mathrm{FeAl}_{3}$ by reacting with aluminum. As a result, the intermetallic compound grew to the transition layer. The growth rate was controlled by the diffusion coefficient of $\mathrm{Fe}$ atoms.

In the second stage, with the increasing of the diffusion of $\mathrm{Fe}$ atoms, the $\mathrm{FeAl}_{3}$ and $\mathrm{Fe}$ atoms reacted to form $\mathrm{Fe}_{2} \mathrm{Al}_{5}$, which is very brittle in nature. It's larger thickness is detrimental to forming properties of the material. The interface of the $\mathrm{Fe}_{2} \mathrm{Al}_{5}$ phase shows highly irregular strip shape morphology (embeded in the transition layer). The thickness of intermetallic compound increased gradually. With the diffusion of $\mathrm{Al}$ atoms, the reaction among $\mathrm{Al}$ atoms $、 \mathrm{FeAl}_{3}$ and $\mathrm{Fe}-\mathrm{Al}$ solid solution occurred: $\mathrm{Al}+\mathrm{Fe} \mathrm{Al}_{3}+\mathrm{Fe}(\mathrm{Al}) \rightarrow \mathrm{Fe}_{2} \mathrm{Al}_{5}$. The saturation atom of $\mathrm{Fe}_{2} \mathrm{Al}_{5}$ is only $70 \%$, and the vacancy density is high. There are a large number of vacancies in the lattice along the $\mathrm{c}$ axis. The $\mathrm{Al}$ atom can diffuse rapidly along the $\mathrm{c}$ axis in the $\mathrm{Fe}_{2} \mathrm{Al}_{5} . \mathrm{Fe}_{2} \mathrm{Al}_{5}$ grew up to form a columnar crystal region(Figure 7(2)(3)).

In the third stage, the diffusion coefficient of $\mathrm{Fe}$ atoms in $\mathrm{Fe}_{2} \mathrm{Al}_{5}$ ( $\eta$ phase)is faster than that of $\mathrm{Al}$ atoms. As a result, $\mathrm{Fe}_{2} \mathrm{Al}_{5}$ grew to the transition layer side. The thickness of the intermetallic compound increased and thickness of the transition layer decreased. The diffusion of $\mathrm{Fe}$ and $\mathrm{Al}$ lead to the growth of $\mathrm{Fe}_{2} \mathrm{Al}_{5}$. Finally, the entire interfacial 
compounds were mainly $\mathrm{Fe}_{2} \mathrm{Al}_{5}$ columnar crystals.

The intermetallic layers can be identified as $\tau_{5}$ phase- $\mathrm{Al}_{8} \mathrm{Fe}_{2} \mathrm{Si}$ (adjacent to steel) and $\tau_{6}$ phase- $\mathrm{Al}_{4.5} \mathrm{FeSi}$ (adjacent to aluminum) by the EDS analysis. The initial Si content of the transition layer was $0.8 \mathrm{wt} \%$ (A point in figure 6). According to the phase diagram of $\mathrm{Al}-\mathrm{Fe}-\mathrm{Si}$, when the concentration of $\mathrm{Si}$ in the interface was more than A point in figure 7, which can decrease the melting point of aluminum alloy and acceleratethe IMC growth at the interface of aluminum-steel[13]. Aluminum alloy at the interface of aluminum alloy melted. The $\mathrm{Fe}_{2} \mathrm{Al}_{5}$ disappeared finally as the content of $\mathrm{Si}$ increasing at the interface. Figure 7c shows that in the high $\mathrm{Si}$ concentrations region, Al-Fe-Si compounds formed at the aluminum-steel. The results of EDS show that the two intermetallic layers were $\tau_{5}$ phase $\left(\mathrm{Al}_{8} \mathrm{Fe}_{2} \mathrm{Si}\right)$ and $\tau_{6}$ phase $\left(\mathrm{Al}_{4.5} \mathrm{FeSi}\right)$, in figure $7 \mathrm{c}$ (4)(5).

According to the report in Ref[14]Si atom was easy to fill the $\mathrm{Fe}_{2} \mathrm{Al}_{5}$ vacancy because of the high vacancy density of $\mathrm{Fe}_{2} \mathrm{Al}_{5}$. For this reason, interfacial compound was two layers.

Vybornov et al.[15]calculated that $\triangle_{\mathrm{f}} \mathrm{H}^{0}\left(\tau_{5}\right)=(-24.5 \pm 2) \mathrm{kJ} / \mathrm{mol} 、 \triangle_{\mathrm{f}} \mathrm{H}^{0}\left(\tau_{6}\right)=(-34.3 \pm$ $2) \mathrm{kJ} / \mathrm{mol}$. The results showed that the formation enthalpy of phase $\tau_{5}$ was the lowest, and the second is phase $\tau_{6}$. The diffusion reaction can be divided into the following two stages.

In the first stage, $\mathrm{Si}$, contained in filler, diffused and penetrated into the interface of aluminum-steel. This lead to the first generation of phase $\tau_{5}\left(\mathrm{Al}_{8} \mathrm{Fe}_{2} \mathrm{Si}\right)$.

In the second stage, diffusion of $\mathrm{Fe}$ through phase $\tau_{5}\left(\mathrm{Al}_{8} \mathrm{Fe}_{2} \mathrm{Si}\right)$ in the transition layer and reacted with $\tau_{5}$ generating phase $\tau_{6}\left(\mathrm{Al}_{4.5} \mathrm{FeSi}\right)$. From the steel layer to the transition layer was $\tau_{5} 、 \tau_{6}$, respectively.

\section{Conclusions}

To sum up, through the study of the brazing behavior of 3003 fin and 4343/4A60/08Al three layers aluminum-steel cladding strip used in power station air cooling system. The conclusion of this paper are listed as follows.

(1) The optimum brazing temperature range was $590{ }^{\circ} \mathrm{C} \sim 595{ }^{\circ} \mathrm{C}$ with a holding time of 10min, Meanwhile, the thickness of the transition layer must be equal to or greater than $134 \mu \mathrm{m}$.

(2) At the condition of brazing temperature less than or euqal to $580{ }^{\circ} \mathrm{C}$, the fluxility of the molten fillers was poor. Many defects were found at the brazing joint.

(3) At the condition of brazing temperature $600{ }^{\circ} \mathrm{C}$, the transition layer was seriously corroded. Moreover, when the transition layer thickness was less than or equal to $112 \mu \mathrm{m}$, the molten filler penetrated through the transition layer, resulted in the intermetallic compounds formation at the aluminum-steel interface.

(4) During brazing progress, $\mathrm{Si}$ in the filler diffused along the grain boundaries of the transition layer and gathered along the interface of transition layer and steel layer, leaded to 
the generation of intermetallic compounds. At the edge of the intermetallic compounds away from the brazing joint, the Si concentration was lower, and the intermetallic compound were mainly $\eta\left(\mathrm{Fe}_{2} \mathrm{Al}_{5}\right)$. In the region nearby brazing joint, with higher concentration of $\mathrm{Si}$, the intermetallic compounds had a two-layer structure. One layer closing to transition layer was mainly $\tau_{5}$, while the other closing to steel layer was mainly $\tau_{6}$.

\section{Acknowledgement}

Authors would like to thank the support from Jiangsu Key Laboratory for Clad Materials (No:BM2014006), International Science \& Technology Cooperation Program of Wuxi (No:CZE02H1504), Program on Jiangsu Science and Technology Achievements Transformation (No:BA2015079).

\section{References}

1. Li, X.Y.Zeng, X.Chen, Ch.Gao, X.J.Zhang, D.J.Zhou. Development of Aluminum-Steel Cladding Strip with Pre-Cladded Brazing Layer Used in Air Cooling System of Power Plants[J]. Materials for Mechanical Engineering, 2015, 39(10):21-28.

2. L.Li, N.Kotobu, F.X.Yin. Progress in cold roll bonding of metals[J]. Science and Technology of Advanced Materials, 2008, 9(2:):1-11.

3. H.D.Manesh, H.S.Sha. Effective parameters on bonding strength of roll bonded $\mathrm{Al} / \mathrm{St} / \mathrm{Al}$ multilayer strips[J]. Journal of Alloys and Compounds, 2009, 476(1/2): 292-299.

4. D.L.Chen. The Study on Aluminum-steel Plate-fin Heat Exchanger Brazing Technology[D]. Lanzhou University of Technology, 2014.

5. F.N.Afshar, J.H.W.de Wit, H.Terryn, J.M.C.Mol. The effect of brazing process on microstructure evolution and erosion performance of a modified AA4XXX/AA3XXX brazing sheet[J]. Erosion Science[M], 2012(58):242-250.

6. Okamoto,T.Takemoto, K.Uchikawa, Brazability and Erosion by Molten Filler Alloy of Aluminum Base Plates with Intermetallic Compounds[D]. Osaka University, 1983.

7. D.J.Schmatz. Grain Boundary Penetration During Brazing of Aluminum[J], Welding Journal, 1983, 62(10): 267-271.

8. D.J.Zhou, Zh.Chen, X.J.Zhang, J.G.Tang. Effect of Si Addition on Intermetallic Compound Layer at Aluminum/Steel Interface Bond by Rolling[J]. Heat Treatment of Metals, 2014, 39(1):456-468.

9. A.W.Ralph. Liquid film migration during aluminum brazing[J]. SAE paper 971848,1997.

10. J.L.Murray, A.J.McAlister. The Al-Si(aluminum-silicon)system[J]. Bulletin of Alloy Phase Diagram, 1984, 5(1):74-84. 
11. J.Vikas, V.C.Srivastava, D.Arpan, R.N.Ghosh. Reactive diffusion in the roll bonded iron-aluminum system[J]. La Metallurgia Italiana, 2006(7/8):55-59.

12. H.Okamoto. Phase Diagrams of Binary Iron Alloys[M]. Materials Park, OH: ASM International, 1993.

13. M.Yousaf, J.Iqbal, M.Ajmal. Variables affecting growth and morphology of the intermetallic layer( $\left(\mathrm{Fe}_{2} \mathrm{Al}_{5}\right)[\mathrm{J}]$. Materials Characterization, 2011:517-525.

14. T.Heumann, M.Dittrichn. Structure charater of the $\mathrm{Fe}_{2} \mathrm{Al}_{5}$ intermetallic compound in hot dip aluminizing process[J]. Z Metallk,1959, 50:617-623

15. M.Vybornov, P.Rogl, F.Sommer F. On the thermodynamic stability and solution behavior of the phases- $\mathrm{Al}_{7.4} \mathrm{Fe}_{2} \mathrm{Si}$ and $\tau_{6^{-}} \mathrm{Al}_{9} \mathrm{Fe}_{2} \mathrm{Si}_{2}[\mathrm{~J}]$. Journal of Alloys and Compounds, 1997, 247(1/2): 154-157. 